\title{
The Evaluation of Polyneuropathies
}

Neurology ${ }^{\circledR}$ 2021;96:1106. doi:10.1212/WNL.0000000000011675

In the article "The Evaluation of Polyneuropathies" by Burns et al., the legend for figure 1 should say that the "blue font indicates predominantly axonal polyneuropathies." The authors regret the error.

\section{Reference}

1. Burns TM, Mauermann ML. The evaluation of polyneuropathies. Neurology. 2011;76(suppl 2)S6-S13.

\section{Decreased GABA-A Binding on FMZ-PET in Succinic Semialdehyde Dehydrogenase Deficiency}

Neurology ${ }^{\circledR}$ 2021;96:1106. doi:10.1212/WNL.0000000000011754

In the article "Decreased GABA-A Binding on FMZ-PET in Succinic Semialdehyde Dehydrogenase Deficiency" by Pearl et al., ${ }^{1}$ the third sentence under the "Anesthetic" subheading in the Methods should read "A bolus dose of $1 \mathrm{mcg} / \mathrm{kg}$ was infused...." The authors regret the error.

\section{Reference}

1. Pearl PL, Gibson KM, Quezado Z, et al. Decreased GABA-A binding on FMZ-PET in succinic semialdehyde dehydrogenase deficiency. Neurology. 2009; 73:423-429.

\section{Sex Differences in Treatment and Outcome After Stroke}

Pooled Analysis Including 19,000 Participants

Neurology ${ }^{\circledR}$ 2021;96:1106. doi:10.1212/WNL.0000000000011946

In the article "Sex Differences in Treatment and Outcome After Stroke: Pooled Analysis Including 19,000 Participants" by Carcel et al., ${ }^{1}$ there is an error in table 2. The cells in row "With symptoms (mRS 1-5)" and column "HeadPoST" should read 1,930/4,414 (43.7) for women and 2,393/6,657 (36.0) for men. The authors regret the error.

\section{Reference}

1. Carcel C, Wang X, Sandset EC, et al. Sex differences in treatment and outcome after stroke: pooled analysis including 19,000 participants. Neurology. 2019;93:e2170-e2180. 


\title{
Neurology
}

\section{Decreased GABA-A Binding on FMZ-PET in Succinic Semialdehyde Dehydrogenase Deficiency}

Neurology 2021;96;1106 Published Online before print March 8, 2021

DOI 10.1212/WNL.0000000000011754

This information is current as of March 8, 2021

\author{
Updated Information \& \\ Services \\ including high resolution figures, can be found at: \\ http://n.neurology.org/content/96/23/1106.2.full \\ References \\ This article cites 1 articles, 1 of which you can access for free at: \\ http://n.neurology.org/content/96/23/1106.2.full\#ref-list-1 \\ Permissions \& Licensing \\ Information about reproducing this article in parts (figures,tables) or in \\ its entirety can be found online at: \\ http://www.neurology.org/about/about_the_journal\#permissions \\ Reprints \\ Information about ordering reprints can be found online: \\ http://n.neurology.org/subscribers/advertise
}

Neurology ${ }^{\circledR}$ is the official journal of the American Academy of Neurology. Published continuously since 1951, it is now a weekly with 48 issues per year. Copyright (C 2021 American Academy of Neurology. All rights reserved. Print ISSN: 0028-3878. Online ISSN: 1526-632X.

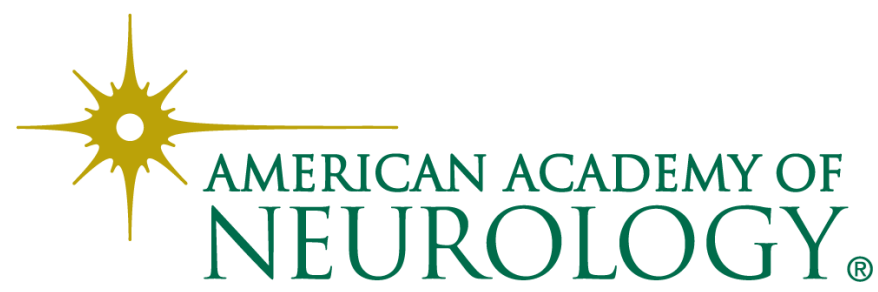

